1 Eruptive dynamics inferred from textural analysis of ash time series: the 2015

4 H. Elizabeth Gaunt ${ }^{1}$, Benjamin Bernard ${ }^{1}$, Silvana Hidalgo ${ }^{1}$, Antonio Proaño ${ }^{1}$, Heather Wright ${ }^{2}$,

$5 \quad$ Patricia Mothes ${ }^{1}$, Evelyn Criollo ${ }^{3}$ and Ulrich Kueppers ${ }^{4}$

6

$7 \quad{ }^{1}$ Instituto Geofísico, Escuela Politécnica Nacional, Quito, Ecuador

$8 \quad{ }^{2}$ U.S. Geological Survey and USAID Office of Foreign Disaster, Assistance, Volcano Disaster

9 Assistance Program (VDAP), Cascades Volcano Observatory, 1300 SE Cardinal Court, Vancouver, 10 WA 98683, USA

$11{ }^{3}$ Departamento de Metalurgia Extractiva, Escuela Politécnica Nacional, Quito, Ecuador

$12{ }^{4}$ Ludwig-Maximilians-Universität München, Earth and Environmental Sciences, Munich, Germany

$13 *$ Corresponding author

14 Email: egaunt@igepn.edu.ec

15

16 Abstract

17 Forecasting future activity and performing hazard assessments during the reactivation of large

18 andesitic volcanoes remain a great challenge for the volcanological community. On August 14,

192015 Cotopaxi volcano erupted for the first time in 73 years after approximately four months of

20 precursory activity, which included an increase in seismicity, gas emissions, and minor ground

21 deformation. Here we discuss the use of near real-time petrological monitoring of ash samples as a

22 complementary aid to geophysical monitoring, in order to infer eruption dynamics and evaluate

23 possible future eruptive activity at Cotopaxi. Twenty ash samples were collected between August

2414 and November 23, 2015 from a monitoring site on the west flank of the volcano. These samples

(C) 2016. This manuscript version is made available under the Elsevier user license

http://www.elsevier.com/open-access/userlicense/1.0/ 
25 contain a range of grain types that we classified as: hydrothermal/altered grains, lithic fragments,

26 potentially juvenile material, and free crystals. The relative proportions of theses grains evolved as

27 the eruption progressed, with increasing amounts of potentially juvenile material and a decrease in

28 hydrothermally altered material. In the initial explosion, potentially juvenile grains are microlite-

29 poor and contain hydrothermal minerals (opal and alunite) in contact with fresh glass. The

30 incorporation of hydrous minerals that are unstable at high temperature in melt would have liberated

$31 \mathrm{H}_{2} \mathrm{O}$ from the hydrothermal system, providing energy to trigger phreatomagmatic eruptions at

32 Cotopaxi; only the initial eruptions preserve textural evidence for this process. Subsequent

33 eruptions were also phreatomagmatic; none of the subsequent eruptions produced high proportions

34 of highly vesicular, microlite-free ash grains, as are typical of high decompression rate magmatic

35 eruptions. The combination of increasing crystallinity and proportion of potentially juvenile grains,

36 and high measured $\mathrm{SO}_{2}$ flux indicate decreasing integrated magma ascent rates and clearing of the

37 hydrothermal system along transport pathways in a system open to gas loss. The near real-time

38 monitoring of ash samples combined with traditional geophysical monitoring techniques during the

39 reawakening of Cotopaxi allowed us to gain a much clearer understanding of events than when

40 using traditional geophysical monitoring alone.

41

42 Key Words

43 Volcanic Ash

$44 \quad$ Volcano Monitoring

45 Cotopaxi volcano

$46 \quad$ Eruption dynamics

$47 \quad$ Hazard assessment

48

49 1. Introduction 
50 The reactivation of andesitic volcanoes is commonly initiated by weeks to months of precursory

51 activity such as increased seismicity, deformation and increased $\mathrm{SO}_{2}$ emissions (e.g., Sparks 2003).

52 This precursory activity can include small explosions and the emission of ash (e.g., Cashman and

53 Hoblitt 2004). These explosions are often interpreted as phreatic or phreatomagmatic, where heat

54 from the rising magma interacts with water in the sub-surface such as in a shallow hydrothermal

55 system or in pore space (MacDonald 1972 and Sheridan and Wohletz 1981). Our ability to monitor

56 the geophysical and geochemical signals from volcanoes has greatly improved our ability to

57 forecast and interpret present and impending eruptive activity. Based on monitoring data, including

58 seismic, geodetic, and gas geochemical data, scientists use both empirical pattern recognition and

59 deterministic and probabilistic models to forecast eruptions (Sparks 2003). These forecasts can also

60 be improved by the interpretation of the nature of material ejected during early, small volume

61 explosive eruptions (e.g., Cashman and Hoblitt 2004).

62

63

64

65

66

67

68

69

70

71

72

73

74
Petrologic monitoring includes the characterization of erupted ash particles, providing a complement to remote monitoring methods. By classifying particles into lithologic and textural categories, and tracking their variations through time, information can be learned about the nature of the explosions, their source depths, the timing of formation of pathway from the magma reservoir to the surface, and the ability for (or rate at which) magma ascends through that pathway (e.g., Ersoy et al., 2006; Miwa et al., 2013; Wright et al., 2012). Quantitative characterization of ash includes measurement of grain size, phase composition, ash grain morphology, particle crystallinity and vesicularity, and componentry of constituents (e.g., Cioni et al. 2014; Eychenne et al., 2012).

The recognition of juvenile magma in ash from early explosions can be difficult, especially where remobilized rocks from the volcanic edifice are similar in composition through time, or where juvenile fragments are highly crystalline. Conventionally, juvenile ash was distinguished based on highly vesicular and/or glassy texture (Watanabe et al. 1999) making it easy to recognize through petrological analysis. However, studies of the ash from the precursory explosions of Mount 
75 St. Helens before the climactic eruption on the 18 May 1980 have shown that juvenile material can

76 be masked by decompression and degassing-driven crystallization (Cashman and Hoblitt 2004).

77 Ash from Mount St. Helens was only recognized as juvenile material after its texture was found to

78 be similar to the cryptodome fragments ejected on the 18 May 1980 and during subsequent

79 eruptions. Indeed, highly crystalline, microlite-rich ash fragments have been recognized as juvenile

80 magma at many volcanoes around the world. For example, at Sakurajima volcano, the distinction

81 between juvenile fragments is not made based on crystallinity, but is distinguished based on the

82 surface texture and luster (Miwa et al. 2009). Additionally, crystal textures can be widely variable

83 within a single eruption (e.g., 1999-2006 Tungurahua eruptions, Wright et al. 2012). The crystal

84 textures of volcanic materials are controlled by their integrated histories of decompression,

85 degassing, and cooling. At relatively high degrees of undercooling (due to relatively rapid cooling,

86 decompression and/or $\mathrm{H}_{2} \mathrm{O}$-loss), crystal nucleation dominates over growth and the resultant

87 crystals are numerous and small in size (e.g., Hammer and Rutherford 2002). Small crystals or microlites (those crystals $<40 \mu \mathrm{m}$ in size) therefore provide important information about magmatic processes just prior to or during eruption. Changes in crystal textures, thereby, indicate changes in magma ascent history which has a major control on the explosivity of the system (Woods and

91 Koyaguchi 1994). For example, crystallinity was found to decrease with: 1) increasing magma 92 supply rate and therefore eruption style at Etna, Tungurahua and Eyjafjallajokull volcanoes

93 (Taddeucci et al. 2004; Wright et al. 2012 and Cioni et al. 2014), 2) decreasing repose interval (and 94 thus possible shallow residence time) at Pinatubo volcano prior to its climactic eruption (Hammer et 95 al. 1999), and 3) with increasing lava effusion rate at Unzen volcano (Nakada and Motomura 1999).

The reawakening of Cotopaxi Volcano provided an exceptional opportunity to study the 97 temporal evolution of ash through the initial stages of renewed eruptive activity. The first ash 98 samples were collected immediately after the first explosions and a high frequency sampling was 99 realized through the three and a half months of eruptive activity. We use standard analysis and 
characterization techniques to track changes in erupted material. Scanning electron microscope (SEM) analysis of both fresh and polished sections was combined with componentry analysis with a stereoscope to show the textural and compositional evolution of the ash. We use these data and textural observations to inform discussion regarding the eruption and potential fragmentation mechanisms, the shallow magmatic plumbing system, and the importance of continuously monitoring eruption products as a complementary aid to classical geophysical monitoring and eruption forecasting.

\section{Cotopaxi volcano}

Cotopaxi volcano is a $5987 \mathrm{~m}$ high ice-capped stratovolcano located in the eastern cordillera of the Ecuadorian Andes (Figure 1A). The volcano lies $50 \mathrm{~km}$ south of the capital city of Quito, Ecuador and has produced both andesitic and rhyolitic eruptive products over its $\sim 560$ kyr history (Hall and Mothes 2008). Andesitic volcanism has dominated the eruptive history of Cotopaxi over the past 4400 years, producing andesitic lava flows, lapilli and ash falls, pyroclastic flows, and triggering lahars with very long runout distances (e.g., Mothes and Vallance 2015). Cotopaxi has erupted several times within the historic record, producing Plinian eruptions and long-lived phases of variably explosive eruptive activity (Pistolesi et al. 2011). Based on historic accounts, several of these eruptive phases began with many months of precursory activity. However, unrest has not always led to eruption. In 2001-2, a period of seismic and geodetic unrest occurred at Cotopaxi, including an inferred intrusion of $20 * 10^{6} \mathrm{~m}^{3}$ of magma (Molina et al., 2008; Hickey et al. 2015).

Cotopaxi`s five eruptive cycles recorded during the historical period (since 1532) have been of andesitic composition with paroxysms ranging between VEI 3 to 4 (Pistolesi et al., 2011). The most intense periods were from 1532-1534, 1742-1744, 1766-1768, 1853-1854 and 1877. With the exception of the 1853 event, each of the other eruptive periods resulted in VEI=4 events, which 
124 included regional ash and lapilli falls, pyroclastic flows and especially the generation of large 125 lahars. Typical tephra fallout volumes are 0.1 to $0.2 \mathrm{~km}^{3}$ (DRE) (Hall and Mothes, 2008). Based on 126 historical records and stratigraphy, eruptive activity at Cotopaxi follows repose periods that ranged 127 from 200 years to a mere 22 years. These eruptions commonly began with vent-clearing Vulcanian 128 style explosions in which abundant altered conduit-plugging rock were expulsed. Subsequently, 129 after the initial conduit opening, sub-Plinian to Plinian style activity ensued, during which time 130 regional ash and lapilli falls were recorded, mostly directed to the W-NW of the cone and 131 depositing a mm-thick dusting of ash in Quito (Hall and Mothers, 2008). Before Cotopaxi's June 1321877 eruption, the detonation sounds produced by ascending gas breaking through the conduit plug 133 were loud enough to have been heard in Pasto, Colombia and Guayaquil, Ecuador (both over 250 $134 \mathrm{~km}$ away). These strong booms occurred a day before the onset of the main eruption (VEI=4) on 26 135 June 1877. Cotopaxi's historically erupted magmas generally are comprised of two pyroxene 136 andesites with $57-62 \% \mathrm{SiO}_{2}, 1.2-1.7 \% \mathrm{~K}_{2} \mathrm{O}$, and a phenocryst assemblage that includes plagioclase, 137 hypersthene, augite, magnetite and olivine (Hall and Mothes, 2008).

139 detailed temporal, observational and geophysical monitoring data at the volcano. The current period 140 of volcanic unrest began in April 2015. An increase in the number of seismic events per time and 141 size of seismic events (Figure 2) at the beginning of April, coupled with small but definite changes 142 in the deformation of the flanks of the volcano (tiltmeter data) signaled the start of this new eruptive 143 phase. In May, $\mathrm{SO}_{2}$ flux from the summit crater began to increase as well, with values increasing 144 from background levels averaging around 28 tons/day to 3000 tons/day (Hidalgo et al. In Prep). On 145 June 4, seismic tremor appeared. Small fumarolic and water vapor plumes were visible beginning 146 June 10. Within vapor plumes, both $\mathrm{BrO}$ and $\mathrm{HCl}$ were detected and airborne Multi-GAS 147 measurements indicated that $\mathrm{SO}_{2}$ formed $>99 \%$ of total sulfur $\left(\mathrm{H}_{2} \mathrm{~S}+\mathrm{SO}_{2}\right)$ (Hidalgo et al., In Prep). 148 Seismic activity generally decreased during the initial weeks of June and remained at a lower level 

preceded the first summit explosions by 12 hours. These initial explosions occurred at 04:02 and 04:07 (UTM-5) on 14 August, producing an ash and gas plume up to $8 \mathrm{~km}$ high. Relatively fine ash

152 fell on local communities to the northwest of the volcano covering over $500 \mathrm{~km}^{2}$ (Bernard et al., 153 Submitted). On August 14, four subsequent ash emission events occurred, at 10:25, 13:45, 14:28 154 and 16:27. These emissions and coincident explosions coincided with the appearance of seismic 155 tremor signals associated with gas and ash emissions and a 3 to 9 -fold increase in the quantity of $156 \mathrm{SO}_{2}$ release to between 12,000 and 24,000 tons/day over the following week (Hidalgo et al, In 157 Prep). Almost four weeks of near continuous ash emissions occurred, producing ash continuously 158 for between an hour and more than 24 hours at a time separated by hours of low level gas/ash 159 emissions (Figure 1B). The amount of ash in the plume dramatically reduced during the week 160 beginning September 11, 2015 which coincided with a decrease in the emission tremor signal and 161 an increase in VT seismicity event rates to 220 events per day (Figure 2). $\mathrm{SO}_{2}$ emission rates 162 fluctuated significantly over this period, but remained relatively high, between 3000 and 10,000 t/d. 163 Temperatures of up to $200{ }^{\circ} \mathrm{C}$ were measured with an IR camera on September 5. A third phase of 164 lower intensity, intermittent ash emissions began on October 4, 2015 after a four week period of high VT seismicity rates. Intermittent, discrete explosions occurred over this period but were not associated with any significantly high volume ash emissions. A fourth phase of ash emissions

167 occurred in November 2015, which produced a much smaller amount of ash. As of the start of 2016, 168 surface activity was mostly limited to the emission of gas and water vapor, although VT seismicity 169 rates remain high. The last ash emission was observed on January 24 but did not leave an 170 observable ash deposit. The total volume of ash produced by this series of activity is $1.2 \times 10^{9} \mathrm{~kg}$ 171 (Bernard et al., Submitted). 
174 The transport of ash in volcanic plumes is dependent upon atmospheric conditions, especially wind 175 speed and direction. Atmospheric transport of ash introduces a sorting effect (e.g., through density 176 differences) therefore, sampling of distal ash can introduce large errors into the analysis due to the 177 removal of different components (e.g., Eychenne et al. 2013). To ensure accurate analysis of ash 178 samples, it is important to choose a sampling site close enough to the volcano and within the main 179 deposition axis to reduce any sorting effects. BNAS is a seismic station from the Instituto Geofísico 180 located on the western flank of the volcano, approximately six kilometers from the summit (Figure 181 3A). Between August and December, $18.8 \mathrm{~kg} / \mathrm{m}^{2}$ of ash fell at BNAS station (Figure 3C). By 182 comparison, the sampling sites BREF, located only $3 \mathrm{~km}$ from the crater on the north flank, and San 183 Elisa, located $11.5 \mathrm{~km}$ from the crater in the southwest flank have accumulated $0.2 \mathrm{~kg} / \mathrm{m}^{2}$ and $<0.1$ $184 \mathrm{~kg} / \mathrm{m}^{2}$ respectively (Figure $3 \mathrm{C}$ ). The proximity of BNAS to the summit and its position directly 185 under the main axis of the ash plume makes it an ideal sampling site to minimize the effects of 186 density sorting in the plume. Four emission episodes were identified in the 2015 eruption sequence. 187 These episodes show typical wax and wane behavior where it was possible to identify periods of 188 high emissions followed by periods of low emissions (Figure 2). The phases are: August 14 to 189 August 15, August 15 to October 2, October 2 to November 4 and November 4 to November 30 190 (Phase 1, Phase 2, Phase 3 and Phase 4 respectively). The distinction between Phase 1 and Phase 2 191 was made due to the change from explosive emissions during the first phase to passive emissions in 192 the second phase. Samples of ash were collected every two to four days throughout the first four 193 weeks of activity and covering all of Phase 1 and Phase $2(14 / 08 / 2015$ - 11/09/2015) from a solar 194 panel at BNAS monitoring station, for a total of 12 samples (Table 1). During these initial two 195 phases of ash emissions (14/8/2015 to $15 / 8 / 2015$ and $15 / 8 / 2015$ to $2 / 10 / 2015)$, when significant 196 amounts of ash were falling during the sample collection, the sampling methodology included 197 collection of an initial sample representing multiple days of ash fall and subsequent collection of a 198 second smaller sample, usually representing one to two hours' worth of fresh ash fall while 199 scientists remained onsite. On the $26^{\text {th }}$ of August, an ashmeter (cf., Bernard 2013) was installed at 
BNAS seismic station to more accurately collect and monitor the quantity of ash emitted (Figure

201 3B). During the latter portion of Phase 2 there was a four-week period of low ash emissions

202

203

204

205

206

207

208

209

210

211

212

213

214

215

216

217

218

219

220

221
$(02 / 09 / 2015-02 / 10 / 2015)$, a total of two samples were collected from the ashmeter. Ash collected with the ashmeters is representative of approximately 1 week of ash fall. During the third phase of emissions (2/10/2015 to 4/11/2015) four samples were collected from the ashmeter, two samples during the first two weeks of high ash emissions and two during the following two weeks of low emissions. During the fourth phase of ash emissions (4/11/2015 - 30/11/2015), two samples were collected from the ashmeter. In total, 20 samples were collected from eruptions from August 14 to November 23, 2015.

Once collected, the ash samples were first dried in an oven over night at $40{ }^{\circ} \mathrm{C}$ and then half the amount of each of the samples was sieved manually up to $63 \mu \mathrm{m}$ (in half-phi) in order to determine grain size distribution and to compare components among a consistent size fraction. The nominally sub-63 $\mu \mathrm{m}$ fraction was analyzed by laser diffraction at the Ludwig-MaximiliansUniversität (LMU) Munich, Germany. 2 - 3 aliquots of approx. $0.1 \mathrm{~g}$ were measured for each sample in a Coulter LS230 to ensure reproducibility. In samples where there was less than 5 grams of ash, the whole sample was sieved and then analyzed. The grains between 350 and $500 \mu \mathrm{m}$ in size were selected for componentry analysis. These grains were washed in water and cleaned in an ultrasonic cleaning bath to remove the fine ash coating. The cleaned grains were then dried in the oven at $40{ }^{\circ} \mathrm{C}$ for an additional day. Grains were then examined under a stereoscopic microscope and classified into one of four different petrographic classifications, as described and characterized below. Ideally, a minimum of 300 grains were classified to ensure a representative sample of the ash however, smaller ash samples did not contain the minimum number of 300 grains of this size; error is therefore larger and the results were omitted from the componentry analysis (SEM analysis was still performed on these samples) (Table 1). For SEM imaging, a small portion of each sample was sieved to the $>125 \mu \mathrm{m}$ size fraction, cleaned in water in an ultrasonic cleaning bath, and dried 
225 again. A selection of these grains was mounted on carbon tape and sputter coated with gold to

226 image surface textures using the SEM in the Departamento de Metalurgia Extractiva (DMEX) in the

227 Escuela Politecnica Nacional in Quito; other grains were mounted in epoxy mounts and polished in

228 order to document the textures of vesicles and crystals within ash grains. Electron microprobe

229 analyses were performed using the JEOL 8900 electron microprobe at the USGS, Menlo Park,

230 California. A 15-keV, 8-nA electron beam with a $3 \mu \mathrm{m}$ spot size was used to analyze glass

231 compositions; $\mathrm{Na}$ and $\mathrm{Si}$ were analyzed first to minimize the effects of Na-loss.

We analyzed 13 samples of ash (Table 1) using a stereoscopic optical microscope. Seven other samples were also analyzed but either did not contain enough grains of the correct size after sieving (e.g., extremely fine-grained ash from the 02/09/2015) or there was not enough sample to begin

237 with (Table 1). We first classified the ash grains into four groups based on grain composition and 238 morphology: hydrothermal/altered grains, lithic fragments, potentially juvenile material, and free crystals. Hydrothermal grains were classified based on their color (including metallic color to

241 and/or the presence of mineral deposits on the surface of the grains or within the vesicles of 242 scoriaceous grains. Lithics fragments were classified according to their dull, opaque but unaltered 243 appearance. Potential juvenile fragments were classified according to their black or dark grey color 244 but more importantly, their glossy appearance and sometimes semi-vesicular nature. Free crystals 245 consist of individual phenocrysts (here, phenocrysts is used to distinguish crystals based on size 246 alone) or fragments of crystals of different minerals containing less than $10 \%$ adhering groundmass 247 material. 
251 Hydrothermal/altered material

252 Surface textures of grains classified as hydrothermal material are characterized by surface alteration 253 and oxidation, producing a red to rusty color and/or covered by secondary mineral precipitates 254 white to metallic in color (Figure 4A, B and C). The grains have a wide range in particle 255 morphology, including irregular angular to sub-angular shape and rounded varieties. Particles span 256 a range of vesicularities. Vesicular scoriaceous particles commonly contain secondary precipitates

257 on outer surfaces and within pore space (Figure 4B). Secondary precipitates include acicular 258 gypsum needles (Figure 4D), abundant free or surface coating-sulfides (Figure 4A inset and C), and 259 white or opaque hydrothermal quartz (vuggy quartz) (Figure 4C). Rounded aggregates of poorly 260 consolidated grains can also be found.

261 Grey Lithics

262 Most commonly, the lithic fragments consist of grey to black andesitic rock fragments with dull, 263 opaque, pitted surfaces (Figure 4D, E and F). These grains vary from blocky to very irregular in 264 shape.

265 Potentially juvenile grains

266 Potentially juvenile grains are distinguished primarily based on their glossy surface texture and 267 unaltered andesitic composition. These grains have been subdivided into two morphologic groups: 268 blocky, and porous. The blocky grains have sub-planar faces and consist of dense, microlite rich 269 clasts with large phenocrysts (Figure 4H and 5C) and sometimes contain large vesicles with thick 270 interstitial groundmass septa (Figure 4G H). These dense grains often exhibited trans-granular and 271 grain boundary micro-fractures with apertures of around $2 \mu \mathrm{m}$ (Figure 5D). Blocky are usually light 272 grey to black in color with a vitreous luster and contain variable amounts of microlites and fresh 273 glass (Figure 4I). The porous grains consist of diktytaxitic lattices of microlite crystals with varying 
274 amounts of interstitial glass and void space between crystal networks (Figure 4H and Figure 5A and

275 B). The grains are highly porous, where pore space represents interstitial space between microlite

276 crystals rather than individual pores surrounded by glass (Figure 5A and B). Energy dispersive

277 spectroscopy (EDS) analysis of the crystals that formed these lattices show that the crystals are a

278 mixture of pyroxene and plagioclase with a small proportion of $\mathrm{Fe} \mathrm{Ti}$ oxides. The variation in

279 groundmass glass contents is visible in SEM images of whole grains (Figure 4H), where microlite

280 networks are present to varying degrees.

281 Free Crystals

282 Free crystals are generally large phenocrysts of plagioclase, with lesser amounts of pyroxene

283 (Figure 4J, K and L). Crystals are generally intact and retain their crystal form. Fragments of free 284 crystals are also present.

5.2 Microlite textures and glass compositions

287 Each particle type contains distinct textural and mineralogical associations between microlite and 288 phenocryst phases, where crystal components common to most ash grains include a combination of 289 plagioclase, pyroxene, and oxide phases, and sparse glass between microlites (crystals $<40 \mu \mathrm{m}$ in 290 size). Hydrothermally altered and oxidized grains are the most petrologically diverse. Grains 291 contain abundant opal, alunite, pyrite, and sparse cristobalite and primary magmatic phases that 292 include plagioclase, pyroxene (clinopyroxene and orthopyroxene), and magnetite (Figure 6). In 293 some cases, alunite fills pore space, in others it forms large portions of ash grains (Figure 6A) and 294 pyrite coats grain surfaces (Figure 6B). In these sections, opal has replaced and pseudomorphs 295 plagioclase (Figure 6C) and pyroxene. These grains contain completely ore nearly completely 296 devitrified, crystalline, or replaced groundmass (Figure 6C). Glass compositions were analyzed 
297 from two ash grains in this category and contain 65.1 and $77 \mathrm{wt} \% \mathrm{SiO}_{2}$, with $\mathrm{FeO}$ and $\mathrm{Na}_{2} \mathrm{O}$

298 contents distinct from analyses of glass in potentially juvenile grains (see below; Table 2).

299 Grey lithic fragments display a range of textures, but generally lack hydrothermal alteration phases.

300 Many lithic grains contain abundant microlites with tabular pyroxene crystals most commonly

301 measuring between 10 to $25 \mu \mathrm{m}$. Fresh glass is not visible between microlites in these grains.

302 Potentially juvenile grains contain the smallest microlite crystals and the greatest proportion of

303 fresh glass. In the most crystalline clasts, pyroxene microlites are generally smaller than in clasts in

304 the lithic category (Figure 6G), measuring between $<1$ and $20 \mu \mathrm{m}$, surrounding phenocrysts of

305 plagioclase (Figure 6), but textures of the most crystalline grains in this class overlap with the finest

306 microlite-rich lithic grains. Some grains further contain fresh glass interstitial between microlites;

307 those microlites include plagioclase and pyroxene (Figure 6H), and also include opal (Figure 6I).

308 Glass compositions from five analyzed ash grains in this group have dacitic compositions (Table 2).

309 The greatest abundance of glassy ash grains is contained in the earliest erupted sample, 15 August

310 2015. Glassy grains contain feldspar microlites surrounded by fresh glass, but also contain opalized

311 feldspar that lacks reaction rims or alteration halos and can contain alunite domains. Glass is fresh,

312 analytical totals range from 96.8-98.6 wt\%; anhydrous glass compositions range from 63.4-66.4

$313 \mathrm{wt} \% \mathrm{SiO}_{2}$ and 7.2-7.9 wt\% $\mathrm{FeO}$ (Figure 7).

$315 \quad 5.3$ Grain size analysis

316 Globally, the ash emitted by Cotopaxi volcano is fine to extremely fine-grained with moderate to

317 poor sorting, positive skewness and platikurtic to mesokurtic distribution. Most of the grain-size

318 distributions are bimodal with a sharp coarse mode (0.0 to $3.7 \mathrm{Phi}$ ) and a flat fine mode (4.0 to 6.3

319 Phi) (Figure 8). It is interesting to note that the grain-size mean or median is mostly controlled by

320 the proportion of coarse and fine mode rather than by their absolute value. The fraction of PM10 
321 (breathable, range 2.5-20.1\%) and PM2.5 (breathable and not settling, range 1.4-7.9\%) is high,

322 producing elevated air pollution in the affected area weeks after the heaviest ash falls. There is not a

323 clear evolution through time, but the grain-size distribution is generally finer during the heaviest ash

324 falls $(14-15 / 08 ; 28 / 08-11 / 09 ; 13-20 / 10)$ whereas the finest ash deposits $(21 / 08 ; 18-25 / 09 ; 23 / 11)$

325 have coarser distributions, potentially resulting from wind reworking of the fine-grained material.

The componentry of ash samples from 2015 eruptions from Cotopaxi volcano shows a strong temporal evolution (Figure 9 and 10). Ash from the initial explosions on the $14^{\text {th }}$ August produced samples dominated by lithic fragments and material from the hydrothermal system (27 and $47 \%$ respectively; Figure 8). Free crystals and possible juvenile fragments make up only a relatively small percentage of that sample (26\% combined). In the following four days of the eruption the percentage of potential juvenile grains began to increase up to $60 \%$, whereas the percentage of hydrothermal material and lithic grains significantly decreased (to 17 and 19\%, respectively)

335 (Figure 9). The relative abundance of hydrothermal material continued to decrease to below 16\% 336 where it remained throughout the rest of the eruption period, whereas the percentage of potentially 337 juvenile material continued to increase (Figure 10) with some small fluctuations. The third phase of 338 emissions began in the week of the October 4. Samples from the third phase of emissions contained 339 predominantly potentially juvenile material at between 66 and $68 \%$, whereas the free crystal 340 content remained below $6 \%$, hydrothermal below $15 \%$ and lithics below $24 \%$. This trend continued 341 throughout the rest of the eruptive events, where the potentially juvenile content consistently stayed 342 above $65 \%$. The lithic content, hydrothermal material and free crystals remained relatively constant 343 throughout emissions through the end of November 2015. 
347 The renewed eruption of Cotopaxi provided a unique opportunity to study the temporal evolution of 348 ash through the reawakening of a large stratovolcano after a long period of quiescence. Samples of 349 ash from the first week of the eruption were rich in lithics, hydrothermally or fumarolicly altered 350 grains and oxidized lithic material (Figure 4C and Figure 10A) (cf. red, altered components were 351 classified 'oxidized lithics' by Pistolesi et al. 2011 in their analysis of Cotopaxi eruptive products 352 over the past 800 years). These samples are representative of material that filled the conduit that 353 was cleared out in the "vent clearing" phase (Figure 10A). Textural heterogeneity to conduit-lining 354 material is expected based on the wide range in eruptive products that form any volcanic edifice. A 355 variation in internal crystal textures to andesitic material belies a range of decompression and ascent 356 histories forming eruptions of differing style and volume through time (e.g., Mothes and Hall 2008).

357 During this initial eruption, the abundance of potentially juvenile material is low, however, the 358 abundance of glass within this material is higher than in other ash samples. High analytical totals to 359 electron microprobe analyses of glass are consistent with lack of alteration. Furthermore, glass 360 compositions are consistent with that expected at Cotopaxi. Figure 7 shows glass compositions from 361 a variety of previous tephra units from Cotopaxi; glass compositions of ash grains in this study have 362 compositions overlapping with previous eruptive units. In contrast, glass compositions from 363 hydrothermally altered components have distinct compositions (Figure 7). The most 364 compositionally similar tephra unit of Pistolesi et al. (2011) is that erupted in small volume explosions that occurred post-1880. The presence of this unaltered glass with compositions not unexpected for Cotopaxi suggest that these grains are fresh, juvenile magma. Furthermore, the presence of fresh, juvenile magma that contains hydrothermal minerals fully coated in fresh melt preserves evidence for magma-hydrothermal system interaction, a potential cause for ensuing phreatomagmatic eruption. 
After the first two weeks which saw the highest ash emission rates (Bernard et al.

371 Submitted), a decrease in the relative proportion of hydrothermally-altered and oxidized fragments

372 is interpreted to represent clearing of an eruptive pathway through the hydrothermal system and

373 altered edifice gas escape network. Over the same interval, the proportion of microlite-rich, blocky

374 fragments in the potentially juvenile component increased. The origin of these fragments includes

375 two possibilities: (A) that the fragments represent unaltered past eruptive products from Cotopaxi,

376 excavated from portions of the edifice that did not experience hydrothermal alteration, vapor-phase

377 alteration from the extensive degassing prior to August 14, or oxidation; or (B) that the fragments

378 represent juvenile magma that degassed and crystallized in response to slow ascent or shallow

379 residence and shallow degassing prior to eruption. Distinction between the possibilities requires a

380 holistic view of the system and comparison with past eruptive products from Cotopaxi. measure on average 28 tons/day since permanent DOAS instruments were installed in $2008 . \mathrm{SO}_{2}$ emission increased in May, remaining high through eruptive/explosive events in August -

386 November. Furthermore, chemical indicators of magmatic degassing were detected by August, 387 where the presence of $\mathrm{BrO}$ was clearly detected in the plume after August 14 (Dinger et al., 2016), 388 indicating magmatic degassing through a dry pathway (cf., Bobrowski et al., 2003). Moreover, 389 measurements of high $\mathrm{SO}_{2} / \mathrm{H}_{2} \mathrm{~S}$ ratios support interpretation of magmatic degassing rather than of a 390 hydrothermal origin. Additionally, no broad deformation was detected via InSAR techniques, 391 however minor deformation $(\leq 1.5 \mathrm{~cm})$ was detected with the GPS and tiltmeter network, consistent 392 with possible minor inflation of the edifice. An observed orange glow within the crater for several 393 days since October 02 also requires elevated (magmatic) temperatures to some phase at the surface.

394 Finally, seismic patterns are consistent with shallow magma residence, including abundant low 

period were substantially elevated above previous levels of monitored unrest at Cotopaxi that were themselves interpreted to result from the intrusion and interaction of shallow hot material (e.g., magma) with water (e.g., in the hydrothermal system; Ruiz et al. 1998). August 2015 is abundant. This evidence combined with the appearance of fresh glass that contains few microlites in the earliest erupted ash and the more microlite-rich material erupted later in the sequence suggests the simplest explanation for componentry changes in ash produced from eruptions starting on 14 August 2015, is the ejection of juvenile magma. As inferred based on microlite textures, this magma ascended relatively rapidly before the first eruption, allowing excavation and incorporation of parts of the hydrothermal system, but prohibiting extensive microlite crystallization. This magma then continued to degas and crystallize as it formed a series of

407 shallow conduit plugs that were erupted in the smaller volume eruptions through November 23.

408 Fluctuations in the relative abundance of lithics and hydrothermal material after a magma-filled 409 pathway reached the surface can be explained by variations in total eruptive volume during any 410 single eruption. For small volume eruptions, the overprint of recycled material from previous 411 eruptions is also likely (Taddeucci et al. 2002; Wright et al. 2012). The small amount of potentially 412 juvenile material in the samples from 14 August explosions presents the strong possibility that new 413 magma was involved and represents the trigger mechanism for the first explosions. The increasing 414 percentage of potentially juvenile magma fragments in the ash as the eruption progressed and the 415 decreasing content of "old" material is partly a function of erupted volume. This suggests a 416 progressive increase in the relative involvement of the magmatic system, but a potential decrease in 417 the integrated ascent rate that this magma experienced. This observation is coherent with the 418 decrease of the seismic tremor associated to the ash emissions during the third and fourth phases 419 (Bernard et al. Submitted) and allows a process explanation for it. 
421 Changes in the crystallinity of the potentially juvenile material results from changing ascent and

422 decompression conditions within the conduit (e.g., Hammer et al., 1999). By comparison with

423 experiments and with ash studies of historic eruptions elsewhere, the presence of glassy ash grains,

424 with low micro-crystallinities suggests relatively rapid ascent of juvenile magma, as was observed

425 most abundantly (but still a minor portion of the eruptive material, Figure 6I, Figure 7) in the

426 August 15 sample. As the eruption sequence continued, these potentially juvenile grains

427 transitioned to higher micro-crystallinity material (Figure 6G and $\mathrm{H}$ ). The presence of high micro-

428 crystallinity eruptive products is likely the result of slow ascent and/or long residence times at

429 shallow levels, as would be expected in a dome or a shallow conduit plug (e.g., Nakada and

430 Motomura 1999; Hammer et al. 1999; Hammer and Rutherford 2002; Cashman and Hoblitt 2004).

431 For example, coarsely vesicular clasts from 2010 Eyjafjallajokull eruptions reached 55\% micro-

432 crystallinity; blast deposits from Mount St. Helens in 1980 reached 62\%; and eruptive products

433 from Colima 1913 and May 2005 eruptions reached $~ 80 \%$ and $~ 90 \%$ micro-crystallinities,

434 respectively (Savov et al. 2008). The increase in crystallinity of the juvenile fragments over the first

435 week of the eruption alludes to a progressive rheological stiffening of the magma which would lead

436 to increasingly lower ascent rates (e.g., Sparks et al 1997 and Cordonnier et al. 2012). Shallow,

437 microlite-rich magma forms a plug in the shallow conduit that is repeatedly fragmented. Repetitive

438 formation and destruction of a shallow magmatic plug in a system that has contained an extensive

439 hydrothermal system, as at Cotopaxi, is also consistent with the ongoing shallow seismicity,

440 including explosion-type signals that persist to the time of this writing even when no surface

441 expression is seen.

After the first week of ash emissions, grains with a diktytaxitic textures (Figure 4A and B)

443 and varying amounts of residual glass appeared and began to increase in abundance. Diktytaxitic

444 textures in andesite magmas are commonly formed by two processes: filter-pressing and gas driven 
445 filter-pressing (e.g., Sisson and Bacon 1999; Pistone et al., 2015). Filter-pressing is a process

446 whereby a matt of crystals compacts under its own weight, expelling the melt phase. Whereas, gas

447 filter-pressing results from the migration of the melt phase from regions of high pressure to regions

448 of low gas pressure along a gas-pressure gradient. Gas-pressure gradients form as a result of varying

449 degrees of crystallization (e.g., Sparks 1997). Regions of melt in between crystals are driven out

450 through flow down the pressure gradient from regions of high to low pressure (Sisson and Bacon

451 1999), leaving behind a crystal lattice with void space where there was once melt. This process has

452 occurred to varying degrees within the conduit of Cotopaxi, resulting in grains with varying

453 amounts of residual glass/melt coating the lattices of microlite crystals. Here both processes are

454 possible however, high measured $\mathrm{SO}_{2}$ fluxes suggest that at least transiently high gas pressures are

455 present in the conduit, we therefore suggest that gas filter-pressing is the most likely process.

456 Although diktytaxitic textures to microlite-rich, potentially juvenile grains imply the presence of

457 transient high gas over-pressures within the shallow conduit, the creation of porosity as interstitial

458 space between crystals has been shown to maintain if not increase permeability in the magma,

459 allowing the escape of gas from the shallow environment (Kushnir et al., 2016). High $\mathrm{SO}_{2}$ fluxes

460 recorded by the surface gas monitoring system support this hypothesis. Coupled with other

461 observations such as the abundance of dense, microlite-rich, micro-fractured ash grains and high

462 measured $\mathrm{SO}_{2}$ emissions, this suggests integrated slow magma ascent rates and residence times

463 sufficient to allow degassing, crystallization of the magma.

$465 \quad 7.3$ Fragmentation mechanisms and eruption dynamics

466 The fragmentation mechanisms for dense, microlite-rich pyroclasts emitted during continuous ash

467 emissions has been somewhat enigmatic. The initial explosions and emission phase over the first

468 two days are interpreted as phreatomagmatic due to the high lithic content, the presence of

469 hydrothermally altered material (including hydrous opal and alunite) encased in fresh melt (Figure 
471 samples (Figure 8). For these explosions, the interaction of magma with fluids in the hydrothermal

472 system and fluids liberated by heating of hydrous minerals in hydrothermally altered rocks may

473 have triggered magma fragmentation and explosion. In contrast, the second, third and fourth

474 eruptive phases were semi-continuous, low-energy ash venting and lacked thermal plumes (max.

475 recorded temperature of $200{ }^{\circ} \mathrm{C}$ ). Heat from rising magma in the conduit will likely have dried out

476 the environment and remove external water sources required for phreatic or phreatomagmatic

477 fragmentation. Likewise, the absence of highly vesiculated pumice or scoria in the ash samples

478 indicates that fragmentation was not the result of bubble wall breakage as expected for the rapid

479 decompression of gas-rich magma (e.g., Alidibirov and Dingwell 1996 and Gardner et al. 1996).

480 Furthermore, magma interactions with water derived from the large summit glacier are more likely

481 to cause discrete explosions or ash emissions than continuous ash emissions. Due to the increase in

482 amount of highly microcrystalline juvenile material, we believe that the fragmentation involves an

483 interplay between gas pressure and magma strength (Ono et al. 1995; Taddeucci et al. 2002). Micro-

484 fractures that were identified in the ash grains most likely formed due to the anisotropic contraction

485 of minerals during cooling (Fredrich and Wong 1986), which can significantly reduce the rock

486 strength. High gas over-pressures can exceed the tensile strength of the rock, forcing fractures apart,

487 causing the magma to shatter in a brittle fashion (Ono et al 1995; Taddeucci et al 2002; Spieler et

488 al., 2004). The fragments of ash are then passively carried out of the vent by the emission of gases.

489 This mode of fragmentation has been shown to generate blocky grains with planar edges

490 representative of the plug/cap rock (Miwa et al., 2013; Taddeucci et al., 2002), as seen in Cotopaxi

491 ash samples. Fine grain size distributions to ash samples suggest that the fragmentation mechanism

492 was very efficient and its constancy may reflect self-similar fragmentation mechanisms throughout

493 the ensuing period of continuous ash emissions. Therefore the decrease of seismic tremor associated

494 to the ash emission during the third and fourth phases (Bernard et al. Submitted) is probably due to 
a cleaner path between the fragmentation source and the surface rather than a change in the eruptive dynamics. This is supported by the deep clean vertical crater observed since September 29.

\subsection{Eruption scenarios and hazard assessment and future activity}

Completely aphyric, glassy fragments are absent, indicating that no single eruption has tapped all the way down to the gas rich magma source region, as has happened in Cotopaxi's past. Large volume past eruptions produced pyroclasts with glassy textures, as are common in the eruptive products from the VEI=4 eruption of 1877 (reference Pistolesi pers. comm). The presence of ash grains that we now recognize as juvenile, with low micro-crystallinities of very finely microcrystalline textures suggests that there is at least a semi-open pathway existed from the magma source to the surface. Pre-eruptive gas emissions indicate that magma was able to freely and effectively degas under "open-system" conditions, reducing the potential for a buildup of large, hazardous gas-overpressures (Woods and Koyaguchi, 1994). Instead, the juxtaposition of glassy groundmass with few growth microlites and hydrothermal minerals/fragments may indicate that initial eruptions were triggered by the interaction of magma with the hydrothermal system.

Furthermore, gas emissions have continued, suggesting that significant gas overpressures are not accumulating in the conduit, potentially decreasing the short term likelihood for a large explosive event (e.g., Eichelberger et al., 1986; Woods and Koyaguchi, 1994; Jaupart 1998). However, an open pathway to the surface may also allow a new batch of magma to ascend easily in the future (e.g., Scandone et al. 2007) and equally, the dynamics of the magmatic system can rapidly change with little warning, resulting in a sudden large explosive eruption as happened at Reventador volcano in 2002 (e.g., Hall et al. 2004 and Samaniego et al., 2008). It is also feasible that not all the intruded magma was expelled during the emission phases and that the semi-open conduit that existed during the ash emission phases now contains a highly crystalline plug of degassed magma. Any future eruptive activity would require a vent-clearing phase to allow the ascent or eruption of a new magmatic pulse. However, only through continued monitoring of the volcano (e.g., 
521 potential forecasts for future activity.

524 The near real-time analysis of ash samples from precursory explosive activity at Cotopaxi volcano

525 during the months of August, September, October and November 2015 was used as a

526 complementary aid to assist with the interpretation of the geophysical monitoring signals.

527 Compositional and textural analysis provided invaluable information about the degree of

528 involvement and the ascent conditions of the newly intruded magma body. Ash analysis in itself

529 cannot and should not be used to inform forecasts about future activity, but can provide perspective

530 about the ascent conditions and dynamics of erupted material. Accurate knowledge of past eruptions

531 helps to constrain possible future eruption scenarios, especially for well-preserved large eruptions.

532 At Cotopaxi in 2015, petrologic monitoring of ash grains was used to complement geophysical

533 monitoring techniques. Based on these studies we conclude that there was new magma involved in

534 ash emissions but that the ascent rate was slow and the system was open to continued gas

535 outgassing and escape, which lowered the short term probability of a large explosive eruption.

536 While ash analysis can help provide crucial information regarding the eruptive dynamics, real time

537 ash analysis also allows ash inhalation hazard assessment. Certain types of ash are extremely

538 hazardous to people's health. For example, eruptive episodes that emit a high proportion of

539 respirable ash, with elevated crystalline silica content or angular glass fragments can cause

540 significant respiratory health problems (Horwell and Baxter 2006). Quick identification of the

541 emission of ash can allow authorities and the population to respond quickly and take action to

542 alleviate the effects of such ashes. 
544 Acknowledgements

545 We would like to acknowledge all members of the Instituto Geofísico, especially those who were

546 involved in the response to the volcanic crisis and who assisted with sample collection and analysis.

547 The authors would like to thank John Pallister and the team from VDAP for insightful discussions,

548 Leslie Hayden at the USGS Menlo Park for help with electron microprobe analyses, and a members

549 of DMEX-EPN for their assistance with the SEM work. This research has been conducted in the

550 context of the Laboratoire Mixte International "Séismes et Volcans dans les Andes du Nord" of

551 IRD. This work is the contribution n ${ }^{\circ} 3$ of the project "Grupo de Investigación sobre la Ceniza

552 Volcánica en Ecuador”.

554 Figure Captions

555 Figure 1. Location map of Cotopaxi volcano and photo taken on 03/09/2015 during an overflight

556 mission by the Instituto Geofísico to measure thermal anomalies and perform Multi-gas

557 measurements.

558 Figure 2. Time line of events. Daily LP and VT seismicity event rates recorded by the seismic 559 monitoring network of the Instituto Geofísico on Cotopaxi. Grey shaded areas show the 4 phases of 560 ash emissions after the initial explosion on the morning of August 14 (the dark grey represents the 561 period of high emissions and the light grey the period of low emissions within the phase) and the 562 yellow arrow indicates the maximum $\mathrm{SO}_{2}$ emission during this period of unrest. Red dashed lines 563 indicate important changes in geophysical monitoring parameters and are indicated in the text. The 564 green stars denote the sample collection dates.

565 Figure 3. (A) Location map of Cotopaxi with the seismic and ashmeter networks. BNAS (west), 566 BREF (north) and San Elisa (south) are labeled on the image. The dashed line represents the extent 567 of Cotopaxi Volcano. (B) Photograph of the ashmeter at BNAS taken on 26/08/15 after its 
568 installation. (C) Cumulative ash fall collected at each sample site between August 14 and the end of $569 \quad$ November 2015.

570 Figure 4. SEM backscatter photomicrographs and stereoscope images of the different classified 571 components of the Cotopaxi ash samples: Hydrothermal material (A, B and C), lithics (D, E and F), 572 potentially juvenile ( $\mathrm{G}, \mathrm{H}$ and $\mathrm{I})$ and free crystals (J, K and L). Altered surfaces (A), pyrite crystals 573 (A inset top and C), cubic quartz (A inset bottom) and infilled vesicles (B) are apparent in the 574 majority of grains along with red and orange oxidation of the grains (C). Pitted and worn surface of 575 lithic fragments are apparent (D) as are fresh fractures in highly microcrystalline grains $(\mathrm{G})$ and 576 residual glass between microlite grains of the juvenile grains $(\mathrm{H})$ with black vitreous fresh surfaces 577 (I). Free crystals retain their euhedral shapes ( $\mathrm{J}$ and $\mathrm{K})$.

578 Figure 5. SEM backscatter photomicrographs of ash grains of important ash textures. (A and B) 579 Ash grains showing diktytaxitic textures (disorganized lattices of plagioclase, pyroxene and Fe-Ti 580 oxide crystals with varying amounts of interstitial glass). (C) Blocky planar-edged grain containing 581 a large plagioclase phenocryst surrounded by microlite. (D) Dense microlite-rich grain containing a 582 thermal fracture.

583 Figure 6. Backscattered electron images of (A-C) hydrothermally altered grains. (A) Alunite (dark 584 gray) covers the bottom half of this grain, opal has replaced plagioclase microlites; (B) pyrite 585 crystals (white) coat the surface of this grain that surrounds opal (dark gray), plagioclase (light 586 gray) and crystalline groundmass; (C) opal replaced plagioclase microlites (see original plagioclase 587 core at image bottom); (D-F) lithic grains: note the abundance of microlites in the groundmass and 588 the lack of visible fresh glass (E) mafic microlites are concentrated along plagioclase crystal 589 margins; (G-I) potentially juvenile grains including: (G) highly microcrystalline grain containing 590 fresh glass interstitial between tabular microlites $<30 \mu \mathrm{m}$ in length; $(\mathrm{H})$ moderately microcrystalline 591 grain containing plagioclase and orthopyroxene in a glassy groundmass; (I) low micro-crystallinity 
592 ash grain containing opal xenocrysts (dark gray), and pyroxene and plagioclase microlites (white 593 and light gray).

594 Figure 7. Glass compositions of potentially juvenile grains and hydrothermally altered grains in 5952015 ash samples superimposed on glass compositions of Holocene pyroclasts from Cotopaxi of 596 Pistolesi et al. (2011).

597 Figure 8. Grain-size distribution of five ash samples from the Cotopaxi eruption (in half-Phi 598 interval). Note that most samples show bimodal distribution with a sharp coarse mode ( 3 Phi) and 599 a flat fine mode. Distributions are positively skewed and platikurtic to mesokurtic.

600 Figure 9. Ash componentry histogram. Percentage of hydrothermal, lithics, free crystal and 601 potentially juvenile grains in 13 samples of ash. 7 other samples were analyzed but there was not a 602 sufficient number of grains for representative analysis and so these results have been omitted.

603 Figure 10. Time series of SEM backscatter photomicrographs of ash samples from (A) 15/08/2015, 604 (B) 19/08/2015, (C) 31/08/2015, (D) 08/09/2015, (E) 25/09/2015, (F) 20/10/2015 and (G)

605 23/11/2015. The sequence of photomicrographs shows the evolution of the ash grains throughout 606 the eruptive sequence.

607 Table 1. Ash sample details. The date corresponds to the date the sample was collected (except 608 where indicated with a $*$ where a fresh sample was collected while scientists were on site). The 609 sample weight refers to the amount of ash collected (from the solar panel, the ashmeter or a 610 combination of both). ** Incomplete grain-size data with minimum analyzed grain size bin of 63 $611 \mu \mathrm{m}$

612 Table 2 Anydrous glass compositions of erupted ash grains from Cotopaxi, 2015.

613 References 
614 Alidibirov M, Dingwell DB (1996) Magma fragmentation by rapid decompression. Nature

$615380(6570): 146-148$

616 Bernard B (2013) Homemade ashmeter: a low-cost, high-efficiency solution to improve tephra

617 field-data collection for contemporary explosive eruptions. J Appl. Volcanol. 2(1):1-9

618 Bernard B., Battaglia J., Proaño A., Hidalgo S., Vásconez F., Hernandez S., Ruiz M. (Submitted to

619 Bulletin of Volcanology, 8 June 2016) Relationship between volcanic ash fallouts and seismic

620 tremor: quantitative assessment of the 2015 eruptive period at Cotopaxi volcano, Ecuador

621 Bobrowski N, Honninger G, Galle B, Platt U (2003) Detection of bromine monoxide in a volcanic

622 plume. Nature 423(6937):273-276

623 Cashman KV, Hoblitt RP (2004) Magmatic precursors to the 18 May 1980 eruption of Mount St.

624 Helens, USA. Geology 32(2):141-144

625 Cioni R, Pistolesi M, Bertagnini A, Bonadonna C, Hoskuldsson A, Scateni B (2014) Insights into

626 the dynamics and evolution of the 2010 Eyjafjallajökull summit eruption (Iceland) provided by

627 volcanic ash textures. Earth and Planetary Science Letters 394:111-123

628 Cordonnier B, Caricchi L, Pistone M, Castro J, Hess KU, Gottschaller S, Manga M, Dingwell DB,

629 Burlini L (2012) The viscous-brittle transition of crystal-bearing silicic melt: Direct observation of 630 magma rupture and healing. Geology

631 Dinger,F., Arellano,S., Battaglia, J., Bobrowski, N., Galle, B., Hernandez, S., Hidalgo, S.,

632 Hörmann, C., Lübcke, P., Platt, U., Ruiz, M., Warnach, S. and Wagner, T. Variations of the

$633 \mathrm{BrO} / \mathrm{SO} 2$ molar ratios during the 2015 Cotopaxi eruption. EGU 2016-1001.

634 Eichelberger JC, Carrigan CR, Westrich HR, Price RH (1986) Nonexplosive silicic volcanism.

635 Nature 323(6089):598-602

636 Ersoy O, Chinga G, Aydar E, Gourgaud A, Evren Cubukcu H, Ulusoy I (2006) Texture

637 discrimination of volcanic ashes from different fragmentation mechanisms: A case study, Mount

638 Nemrut stratovolcano, eastern Turkey. Computers \& Geosciences 32(7):936-946 
640 bimodal grain-size distribution of tephra fall deposited during the August 2006 Tungurahua

641 eruption (Ecuador). Bulletin of Volcanology 74(1):187-205

642 Eychenne J, Le Pennec J-L, Ramón P, Yepes H (2013) Dynamics of explosive paroxysms at open-

643 vent andesitic systems: High-resolution mass distribution analyses of the 2006 Tungurahua fall

644 deposit (Ecuador). Earth and Planetary Science Letters 361:343-355

645 Fredrich JT, Wong TF (1986) Micromechanics of thermally induced cracking in three crustal rocks.

646 Journal of Geophysical Research 91(B12):12743-12764

647 Gardner JE, Thomas RME, Jaupart C, Tait S (1996) Fragmentation of magma during Plinian

648 volcanic eruptions. Bulletin of Volcanology 58(2-3):144-162

649 Hall M, Ramón P, Mothes P, LePennec JL, García A, Samaniego P, Yepes H (2004) Volcanic

650 eruptions with little warning: the case of Volcán Reventador's Surprise November 3, 2002 Eruption,

651 Ecuador. Revista geológica de Chile 31:349-358

652 Hall M, Mothes P (2008) The rhyolitic-andesitic eruptive history of Cotopaxi volcano, Ecuador.

653 Bull. Volcanol. 70(6):675-702

654 Hammer EJ, Cashman VK, Hoblitt PR, Newman S, (1999) Degassing and microlite crystallization 655 during pre-climactic events of the 1991 eruption of Mt. Pinatubo, Philippines. Bull. Volcanol.

$656 \quad 60(5): 355-380$

657 Hammer JE, Rutherford MJ (2002) An experimental study of the kinetics of decompression-

658 induced crystallization in silicic melt. Journal of Geophysical Research: Solid Earth 107(B1):ECV

659 8-1-ECV 8-24

660 Hickey J, Gottsmann J, Mothes P (2015) Estimating volcanic deformation source parameters with a

661 finite element inversion: The 2001-2002 unrest at Cotopaxi volcano, Ecuador. Journal of

662 Geophysical Research: Solid Earth 120(3):1473-1486

663 Hidalgo, S. Battaglia, J., Arellano, S., Sierra, D., Parra, R., Bernard, B. (In Prep) Seismic and

664 geochemical signals of unrest and eruption of Cotopaxi volcano in 2015 
665

666

667

668

669

670

671

$672 \quad 71$

673 Macdonald, G.A., 1972, Volcanoes: Englewood Cliffs, NJ, Prentice-Hall, 510 p

674 Miwa T, Toramaru A, Iguchi M (2009) Correlations of volcanic ash texture with explosion

675 earthquakes from vulcanian eruptions at Sakurajima volcano, Japan. Journal of Volcanology and

676 Geothermal Research 184(3-4):473-486

677 Miwa T, Geshi N, Shinohara H (2013) Temporal variation in volcanic ash texture during a

678

679

680

681

682

683

684

685

686

687

688

689

690

Horwell CJ, Baxter PJ (2006) The respiratory health hazards of volcanic ash: a review for volcanic risk mitigation. Bulletin of Volcanology 69(1):1-24

Jaupart C (1998) Gas loss through conduit walls during eruption. Geological Society, London, Special Publications 145:73-90

Kushnir ARL, Martel C, Bourdier J-L, Heap MJ, Reuschlé T, Erdmann S, Komorowski J-C, Cholik N (2016) Probing permeability and microstructure: Unravelling the role of a low-permeability dome on the explosivity of Merapi (Indonesia). Journal of Volcanology and Geothermal Research 316:56vulcanian eruption at the Sakurajima volcano, Japan. Journal of Volcanology and Geothermal Research 260:80-89

Molina I, Kumagai H, García-Aristizábal A, Nakano M, Mothes P (2008) Source process of verylong-period events accompanying long-period signals at Cotopaxi Volcano, Ecuador. Journal of Volcanology and Geothermal Research 176(1):119-133

Mothes PA, Vallance JW (2015) Chapter 6 - Lahars at Cotopaxi and Tungurahua Volcanoes, Ecuador: Highlights from Stratigraphy and Observational Records and Related Downstream Hazards A2 - Papale, John F. ShroderPaolo. In: Volcanic Hazards, Risks and Disasters. Elsevier, Boston, pp 141-168

Nakada S, Motomura Y (1999) Petrology of the 1991-1995 eruption at Unzen: effusion pulsation and groundmass crystallization. Journal of Volcanology and Geothermal Research 89(1-4):173-196

Ono K, Watanabe K, Hoshizumi H, Ikebe S-i (1995) Ash eruption of the Naka-dake crater, Aso volcano, southwestern Japan. Journal of Volcanology and Geothermal Research 66(1-4):137-148 
691 Pistolesi M, Rosi M, Cioni R, Cashman KV, Rossotti A, Aguilera E (2011) Physical volcanology of 692 the post-twelfth-century activity at Cotopaxi volcano, Ecuador: Behavior of an andesitic central 693 volcano. Geol. Soc. Am. Bull

694 Pistone M, Arzilli F, Dobson KJ, Cordonnier B, Reusser E, Ulmer P, Marone F, Whittington AG, 695 Mancini L, Fife JL, Blundy JD (2015) Gas-driven filter pressing in magmas: Insights into in-situ 696 melt segregation from crystal mushes. Geology

697 Ruiz M, Bertrand G, Chatelain J-L, Yepez H, Hall M, Ramon P (1998) Possible causes for the 698 seismic activity observed in Cotopaxi Volcano, Ecuador. Geophysical Research Letters

$699 \quad 25(13) 2305: 2308$

700 Samaniego P, Eissen J-P, Le Pennec J-L, Robin C, Hall ML, Mothes P, Chavrit D, Cotten J (2008)

701 Pre-eruptive physical conditions of El Reventador volcano (Ecuador) inferred from the petrology of 702 the 2002 and 2004-05 eruptions. Journal of Volcanology and Geothermal Research 176(1):82-93

703 Savov IP, Luhr JF, Navarro-Ochoa C (2008) Petrology and geochemistry of lava and ash erupted 704 from Volcán Colima, Mexico, during 1998-2005. Journal of Volcanology and Geothermal 705 Research 174(4):241-256

706 Scandone R, Cashman KV, Malone SD (2007) Magma supply, magma ascent and the style of 707 volcanic eruptions. Earth and Planetary Science Letters 253(3-4):513-529

708 Sheridan MF, Wohletz KH (1981) Hydrovolcanic Explosions: The Systematics of Water-Pyroclast 709 Equilibration. Science 212(4501):1387-1389

710 Sisson TW, Bacon CR (1999) Gas-driven filter pressing in magmas. Geology 27(7):613-616

711 Sparks RSJ (2003) Forecasting volcanic eruptions. Earth and Planetary Science Letters 210(1-2):1$712 \quad 15$

713 Sparks RSJ (1997) Causes and consequences of pressurisation in lava dome eruptions. Earth and 714 Planetary Science Letters 150(3-4):177-189

715 Spieler O, Kennedy B, Kueppers U, Dingwell DB, Scheu B, Taddeucci J (2004) The fragmentation 716 threshold of pyroclastic rocks. Earth and Planetary Science Letters 226(1-2):139-148 
717 Taddeucci J, Pompilio M, Scarlato P (2002) Monitoring the explosive activity of the July-August

7182001 eruption of Mt. Etna (Italy) by ash characterization. Geophys. Res. Lett. 29(8):71-71-71-74

719 Taddeucci J, Pompilio M, Scarlato P (2004) Conduit processes during the July-August 2001

720 explosive activity of Mt. Etna (Italy): inferences from glass chemistry and crystal size distribution

721 of ash particles. Journal of Volcanology and Geothermal Research 137(1-3):33-54

722 Watanabe K, Danhara T, Watanabe K, Terai K, Yamashita T (1999) Juvenile volcanic glass erupted

723 before the appearance of the 1991 lava dome, Unzen volcano, Kyushu, Japan. Journal of

724 Volcanology and Geothermal Research 89(1-4):113-121

725 Woods AW, Koyaguchi T (1994) Transitions between explosive and effusive eruptions of silicic

726 magmas. Nature 370(6491):641-644

727 Wright HMN, Cashman KV, Mothes PA, Hall ML, Ruiz AG, Le Pennec JL (2012) Estimating rates

728 of decompression from textures of erupted ash particles produced by 1999-2006 eruptions of

729 Tungurahua volcano, Ecuador. Geology 40(7):619-622

730 


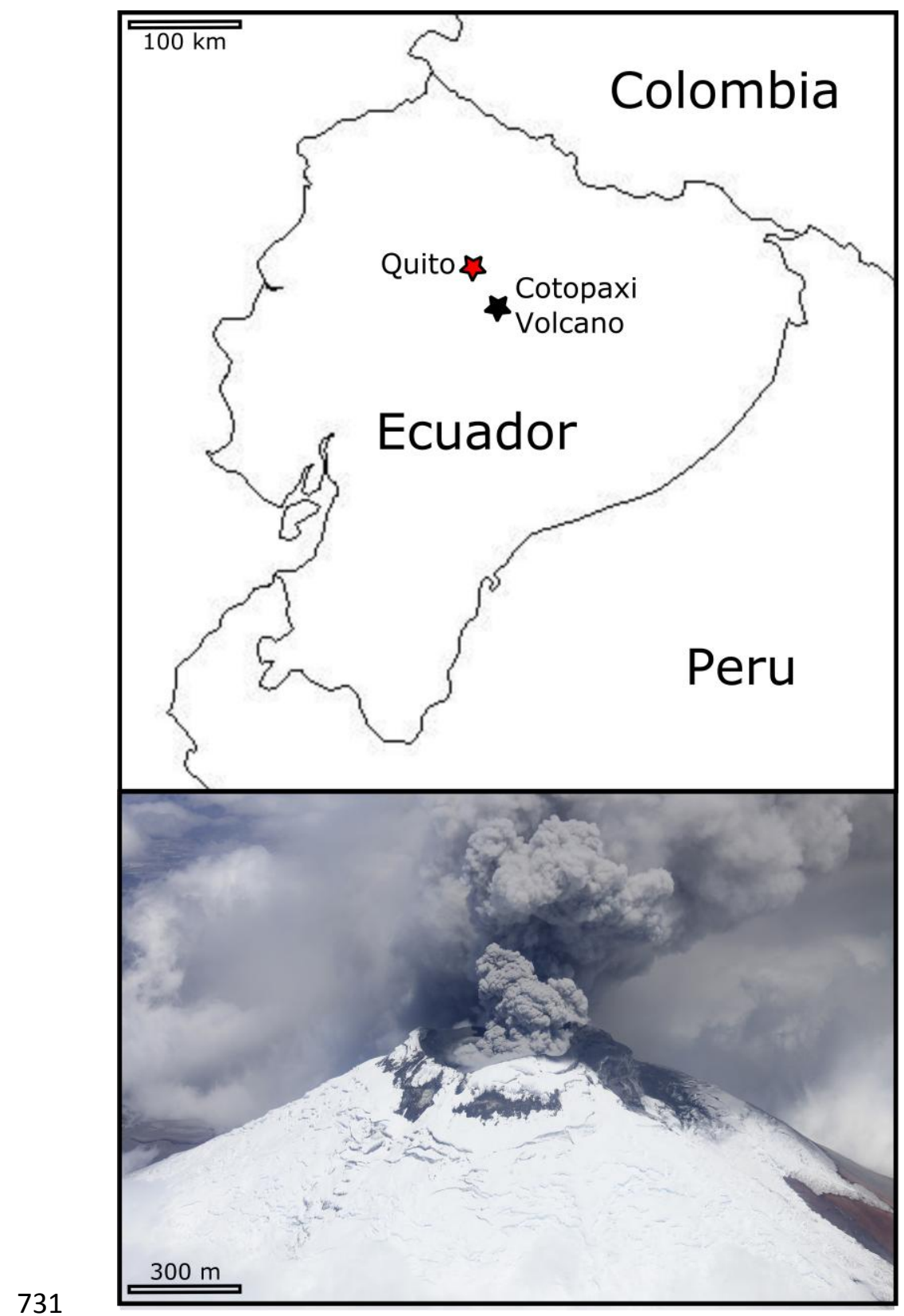




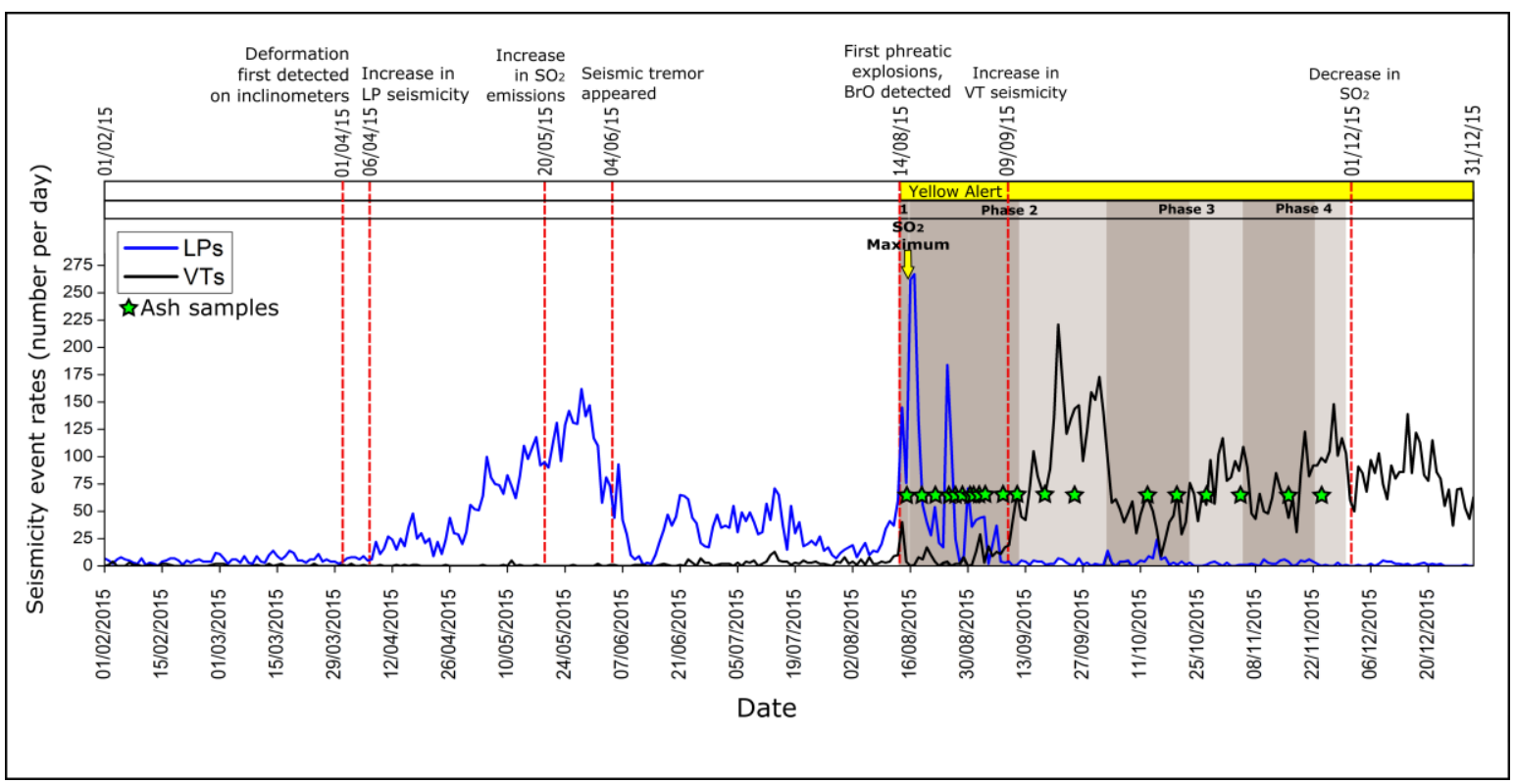




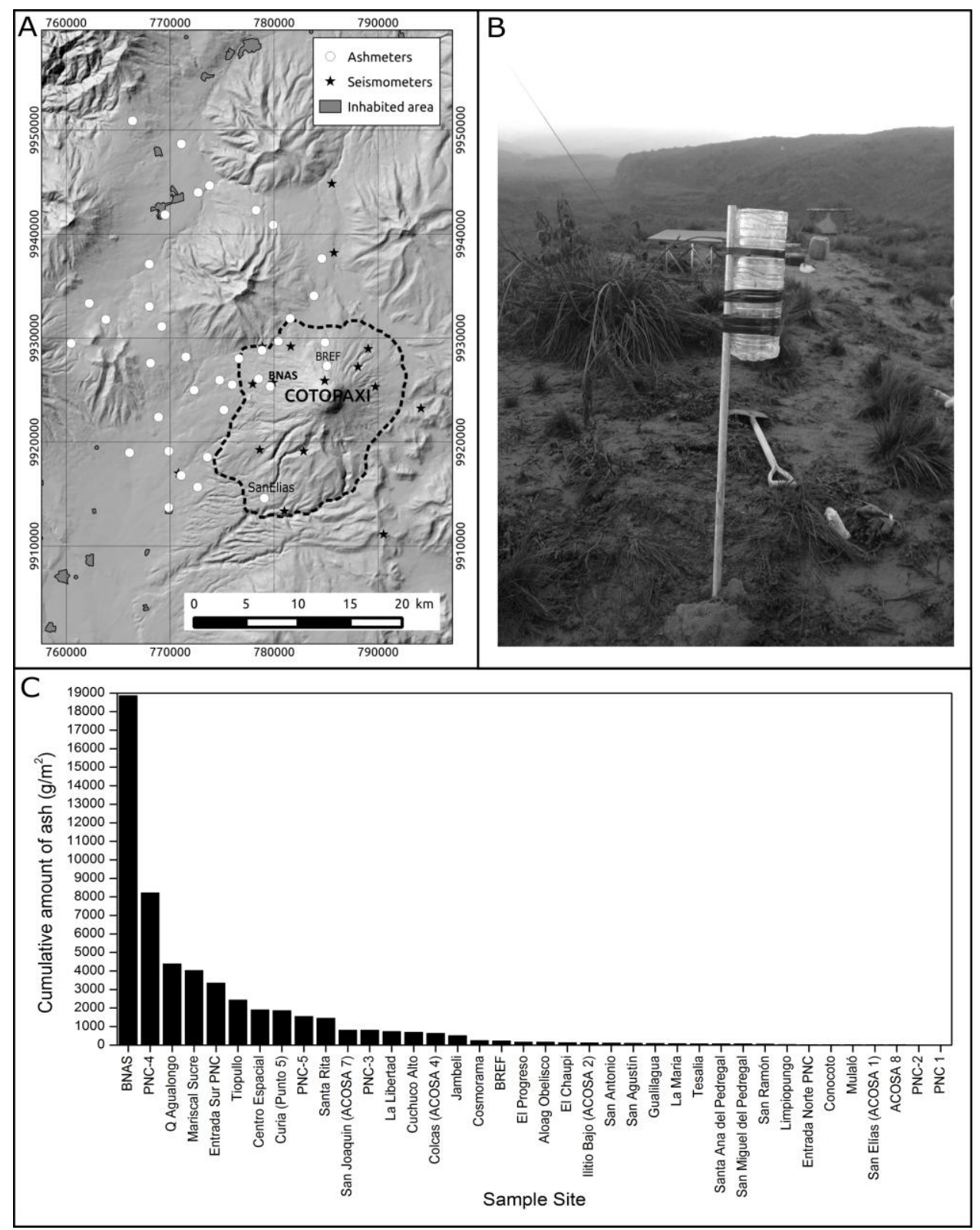

736 


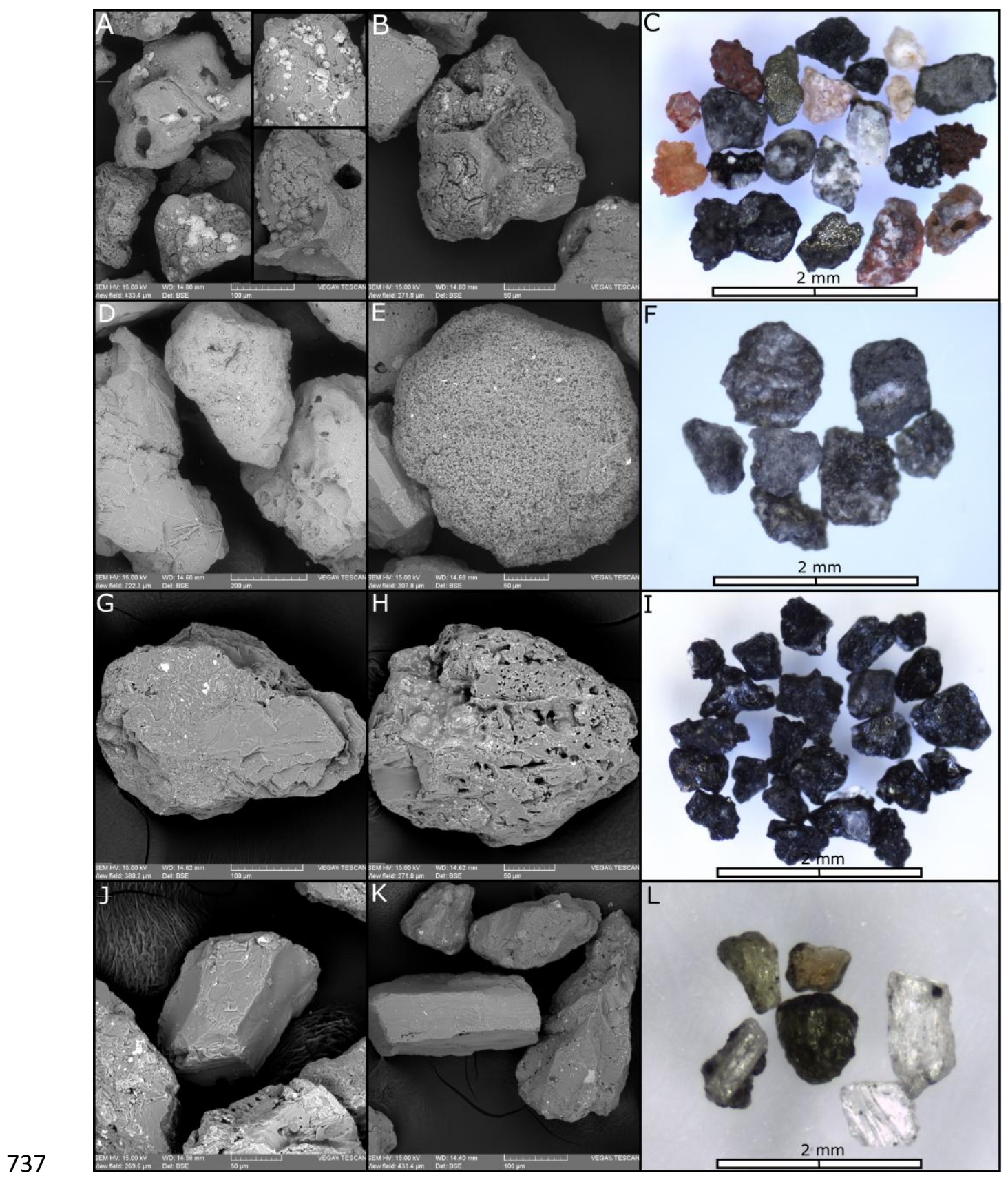

738 

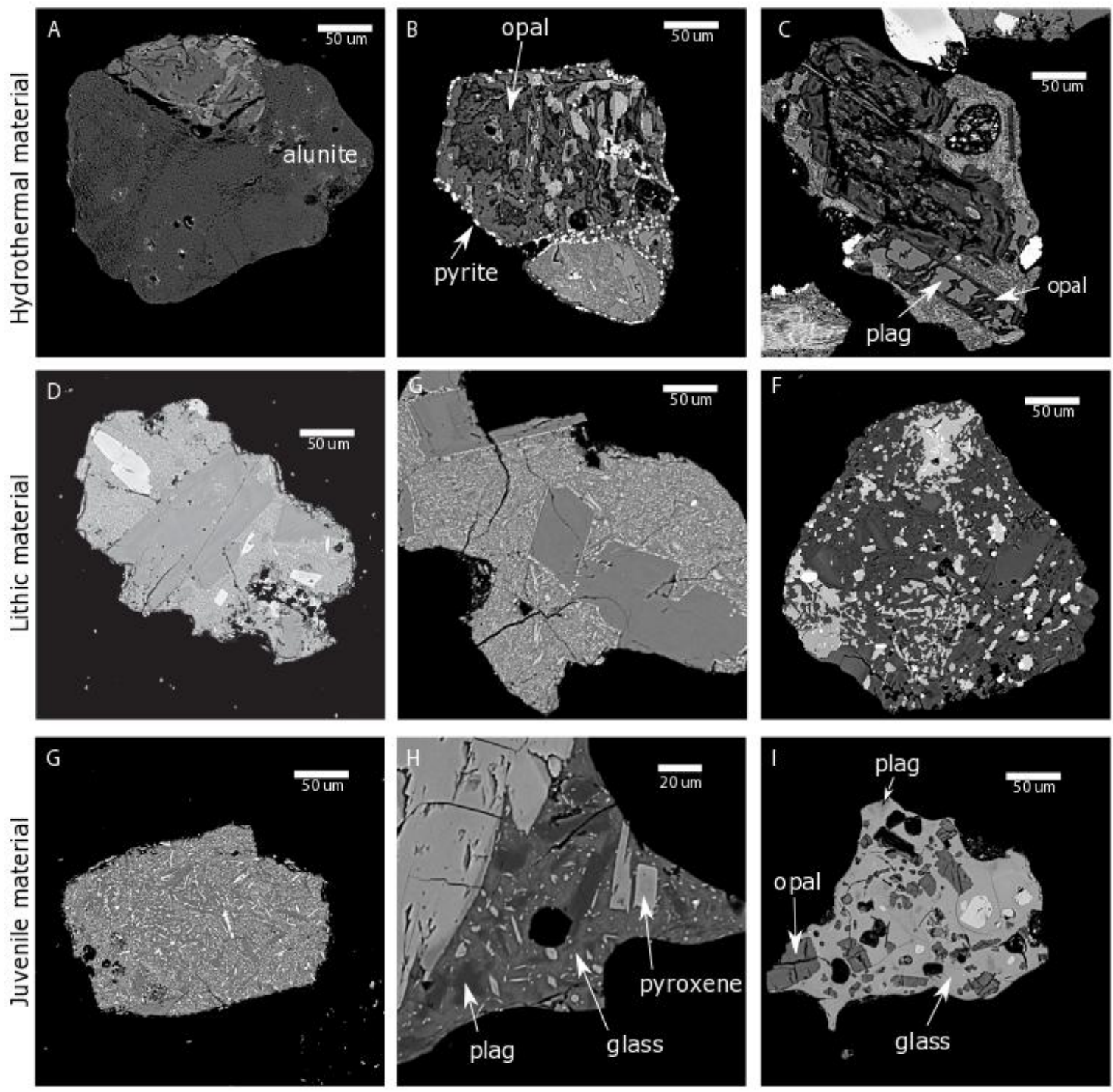


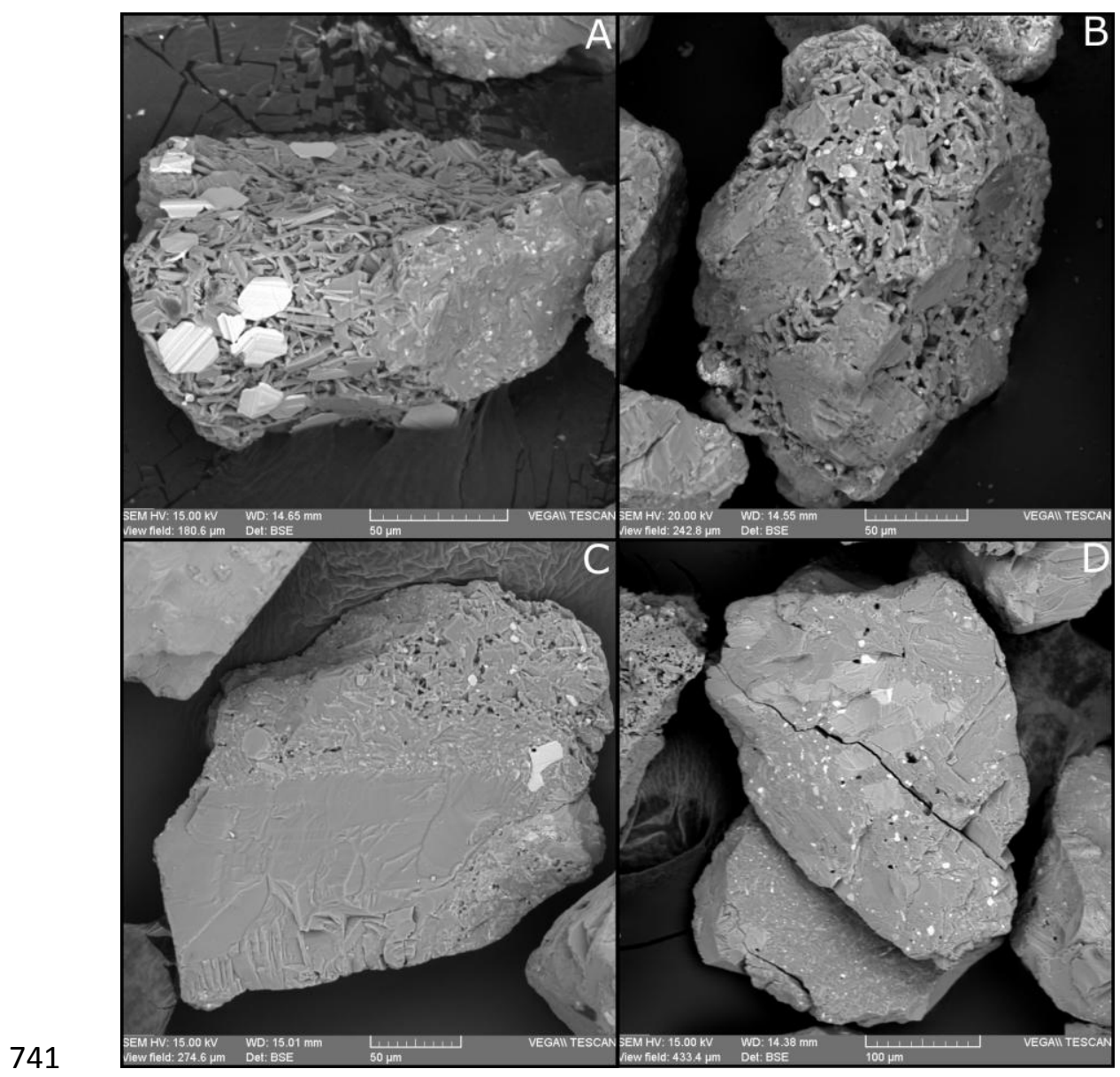

742 


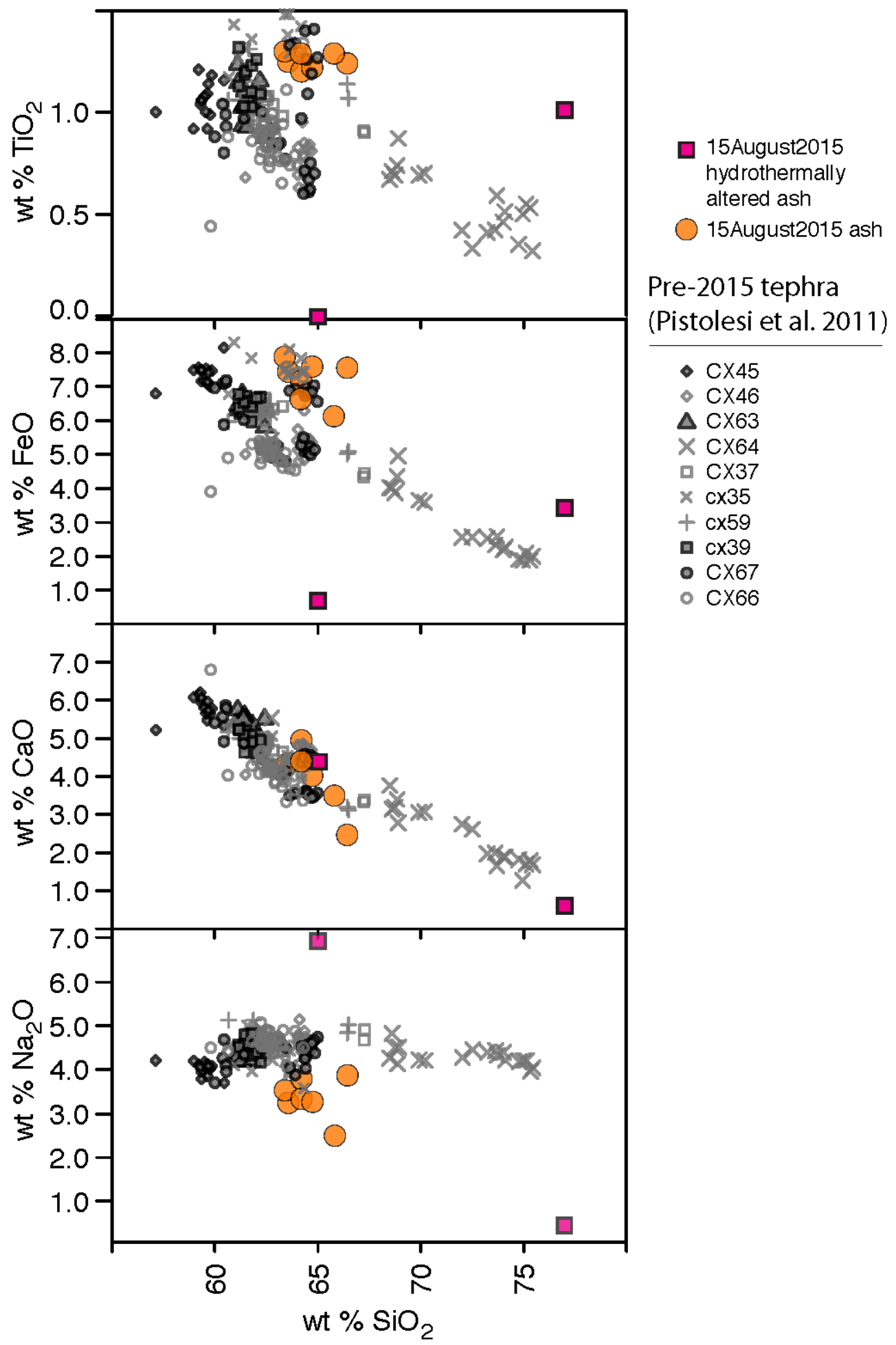




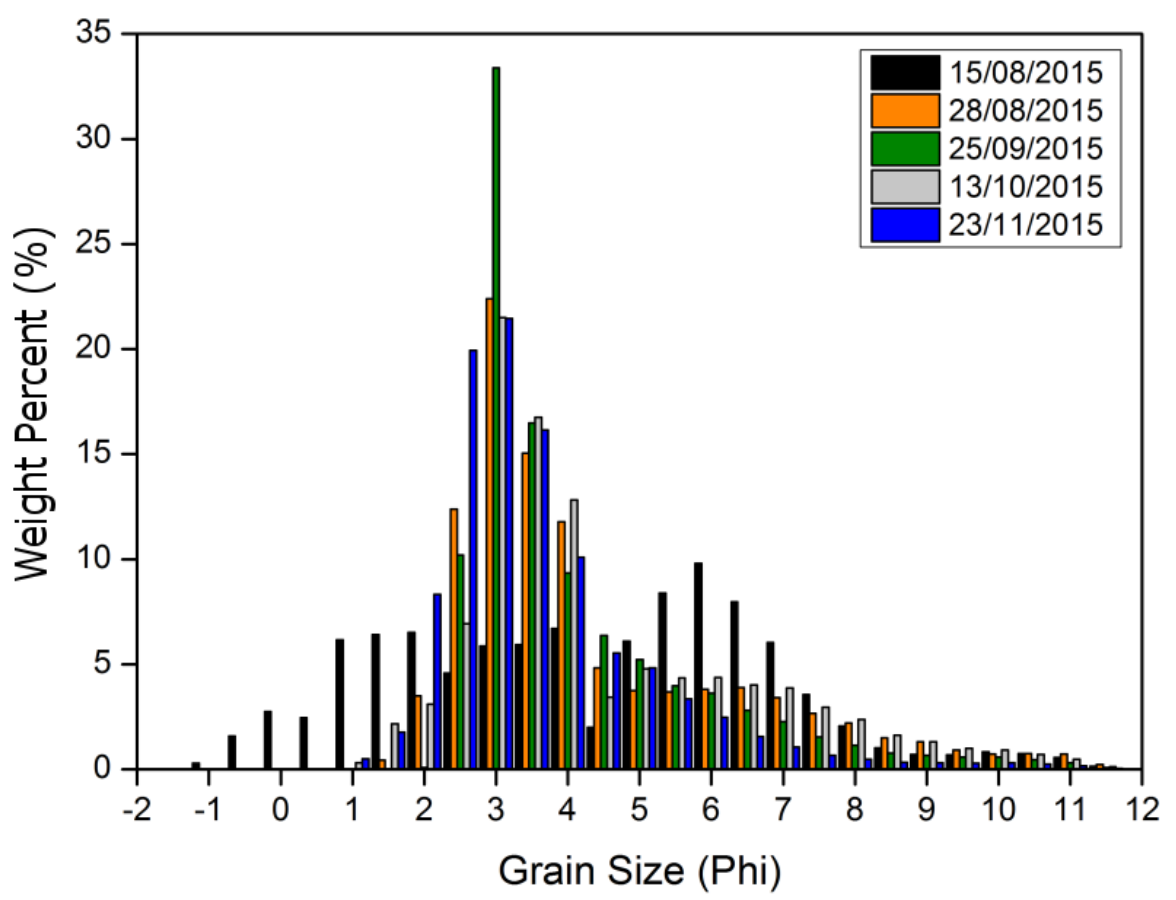

745

746 


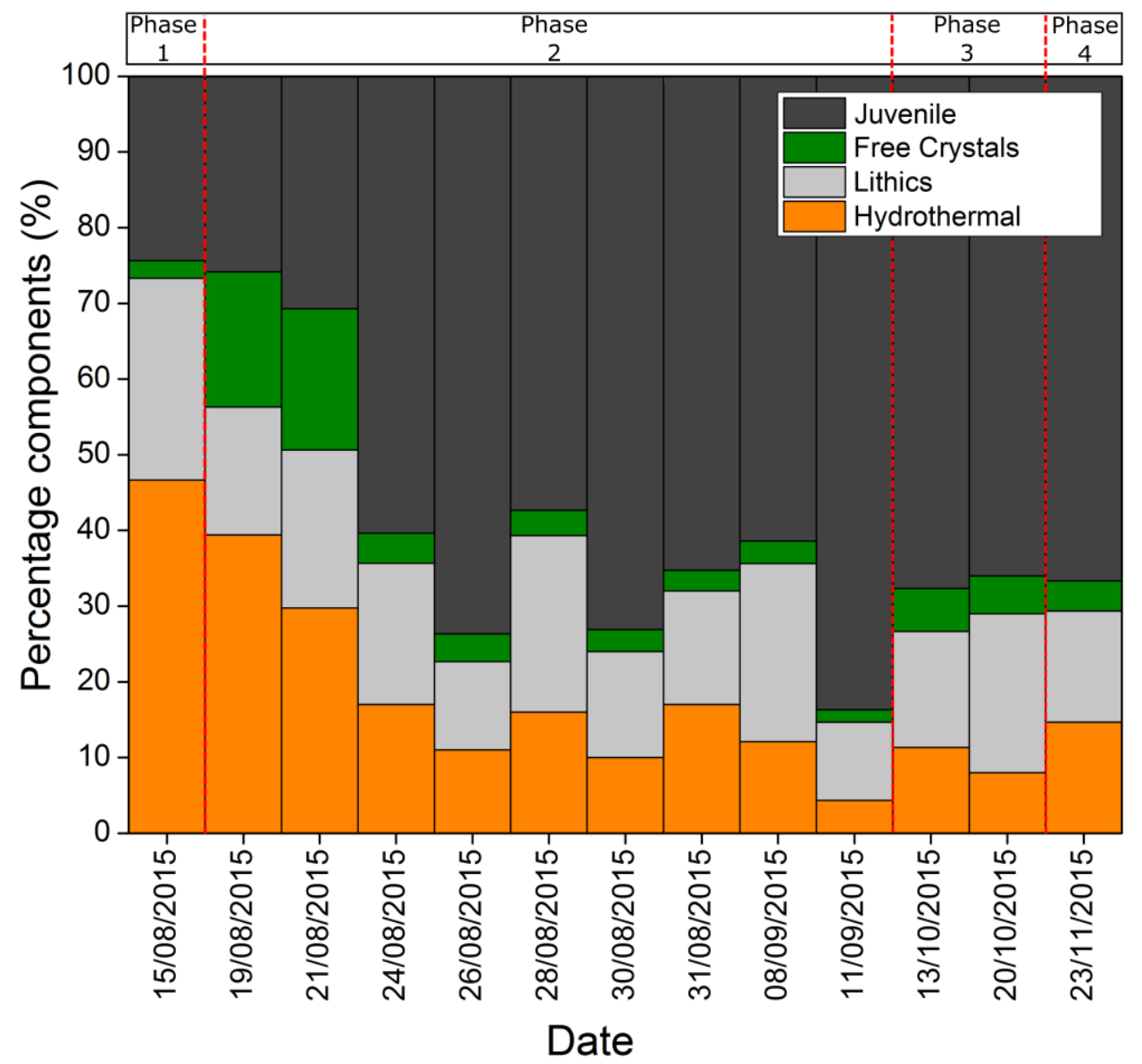



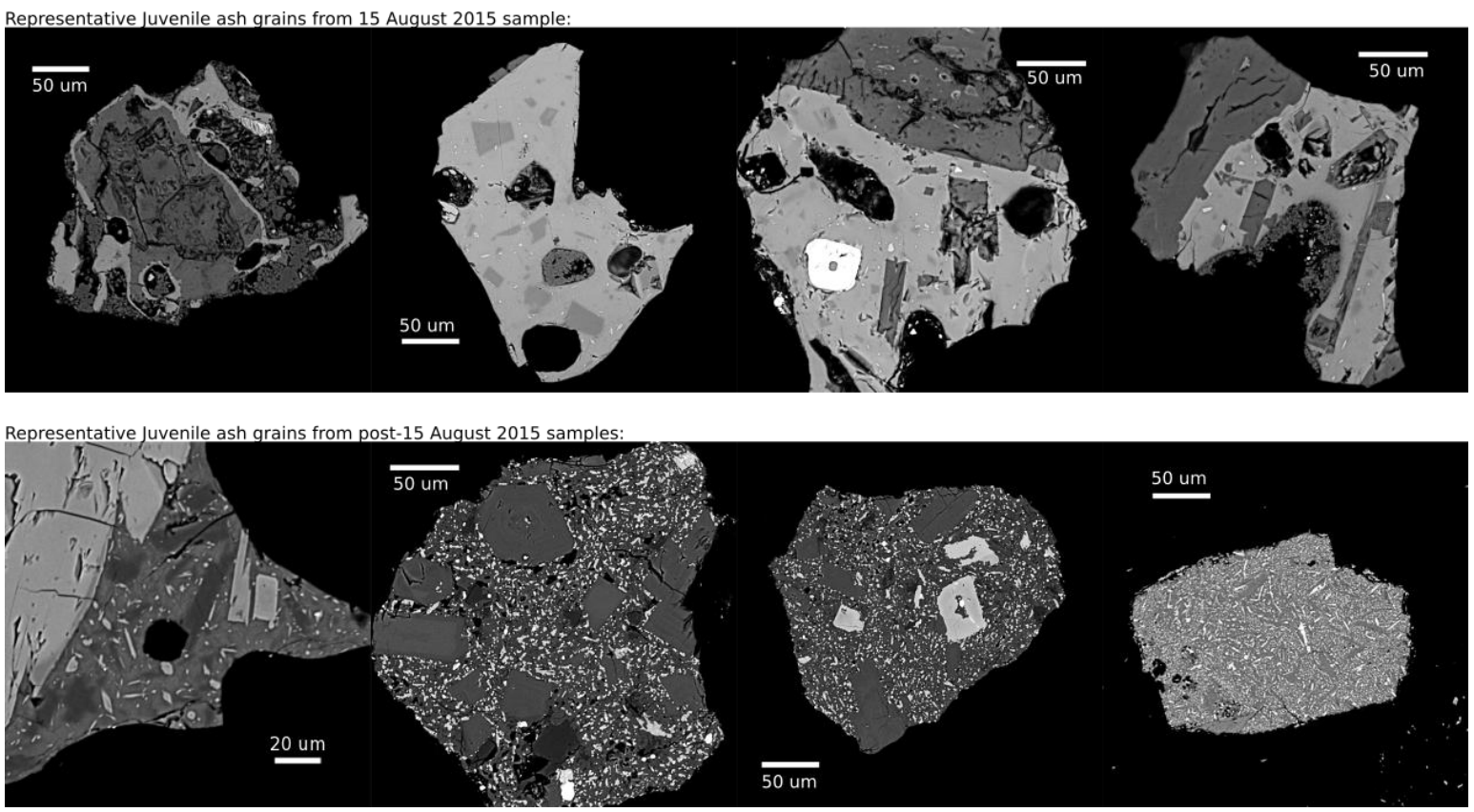


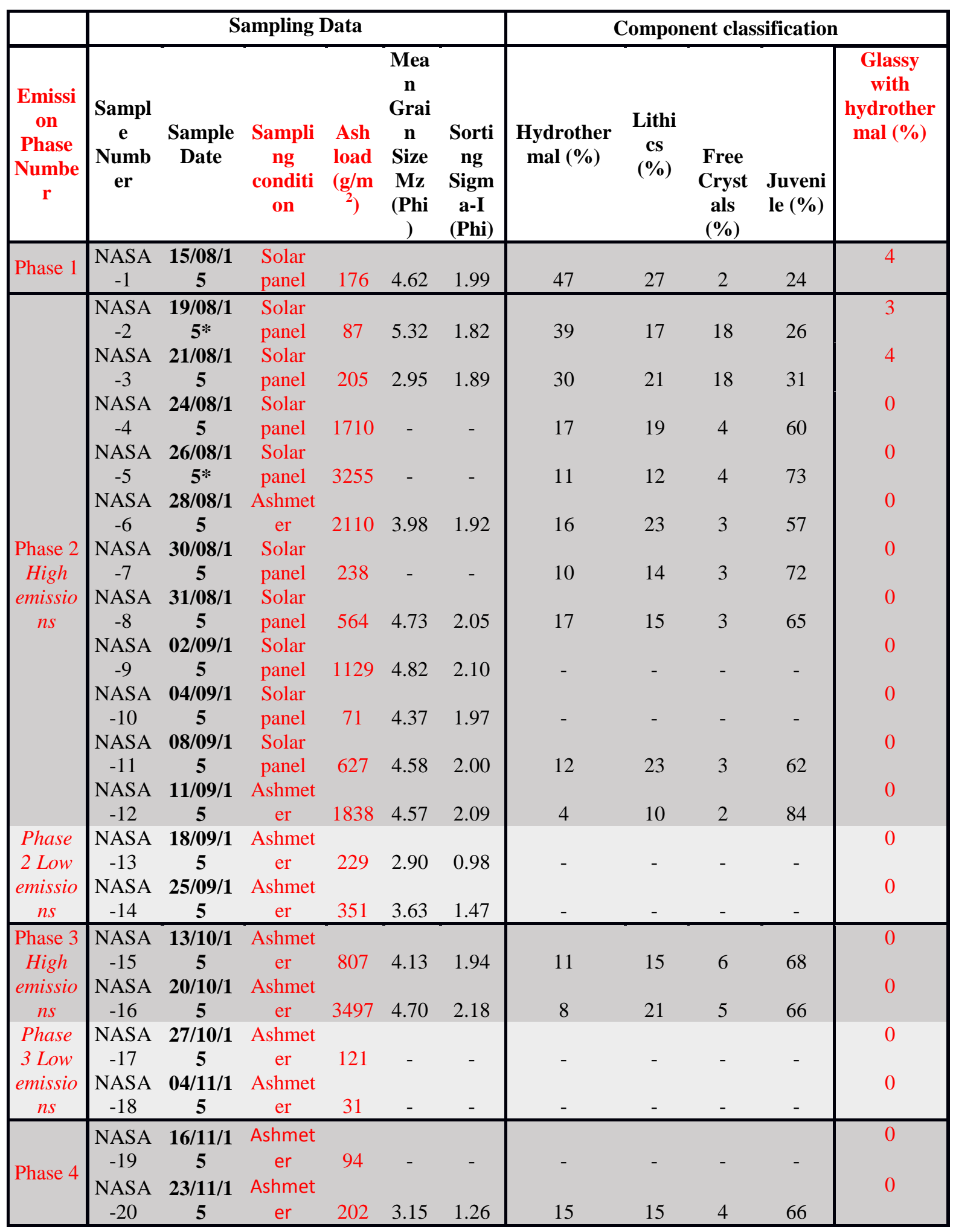




\begin{tabular}{|c|c|c|c|c|c|c|c|c|c|c|c|c|c|}
\hline \multicolumn{2}{|c|}{ Sample Details } & \multirow[b]{2}{*}{$\mathrm{SiO}_{2}$} & \multicolumn{11}{|c|}{ Glass Chemistry (wt.\%) } \\
\hline $\begin{array}{l}\text { Sample Date and } \\
\text { Grain designation }\end{array}$ & $\begin{array}{c}\text { \# of } \\
\text { analyses }\end{array}$ & & $\mathrm{TiO}_{2}$ & $\mathbf{A l}_{2} \mathbf{O}_{3}$ & $\mathrm{FeO}$ & MnO & MgO & $\mathrm{CaO}$ & $\mathrm{Na}_{2} \mathrm{O}$ & $\mathbf{K}_{2} \mathbf{O}$ & $\mathbf{C l}$ & $\mathbf{P}_{2} \mathbf{O}_{5}$ & $\begin{array}{c}\text { Unnormalized } \\
\text { total }\end{array}$ \\
\hline 15August 2015 B1 & 9 & 63.6 & 1.3 & 14.3 & 7.4 & 0.2 & 1.6 & 4.3 & 3.2 & 3.5 & 0.09 & 0.6 & 98.65 \\
\hline 15August 2015 B3 & 5 & 66.4 & 1.2 & 13.5 & 7.6 & 0.1 & 1.1 & 2.5 & 3.9 & 3.0 & 0.08 & 0.6 & 96.82 \\
\hline 15August $2015 \mathrm{BW} 2$ & 9 & 64.2 & 1.3 & 14.5 & 6.7 & 0.0 & 1.9 & 4.4 & 3.8 & 2.6 & & & 97.52 \\
\hline 15August $2015 \mathrm{BW} 3$ & 6 & 64.2 & 1.2 & 14.3 & 7.2 & 0.2 & 1.9 & 4.9 & 3.3 & 2.1 & 0.04 & 0.6 & 96.88 \\
\hline 15August 2015 BW4 & 9 & 64.7 & 1.2 & 14.5 & 7.6 & 0.1 & 1.6 & 4.0 & 3.3 & 2.3 & 0.10 & 0.6 & 97.12 \\
\hline 15August 2015 BW6 & 10 & 65.8 & 1.3 & 13.7 & 6.2 & 0.0 & 1.6 & 3.5 & 2.5 & 4.9 & & & 97.70 \\
\hline \multicolumn{14}{|c|}{ Hydrothermal } \\
\hline 15August $2015 \mathrm{P} 2$ & 5 & 65.1 & 0.0 & 23.9 & 0.9 & 0.0 & 0.0 & 6.4 & 6.9 & 0.9 & & & 97.70 \\
\hline
\end{tabular}

